\title{
OBSERVATIONS ABOUT THE USE OF LEGISLATIVE HISTORY
}

\author{
KENNETH W. STARR*
}

One of the workaday tools which federal judges are called upon to employ regularly in their daily labors is the body of materials called "legislative history." Like a trusty old teapot, legislative history is readily available whenever the need for it arises. Indeed, in the current era legislative history truly abounds, with library specialists compiling vast tomes designed to aid lawyers and judges in divining the meaning of statutory law. Today, as courts toil under burgeouning case loads, we pause to examine whether (and to what extent) we may be, as it were, drinking too mucli tea.

\section{BACKGROUND}

\section{A. The State of the Federal Courts.}

That the federal judiciary is laboring under an mcreasing case load is a truism. There are presently about 200,000 civil cases pending in the federal district courts, and the courts of appeals have a docket of almost 20,000 cases at any particular time. The growing volume of cases is exacerbated by what many judges perceive as increasing substantive difficulty in individual cases.

Along with the increased case load, the role of the federal courts has changed: the federal courts in the post-Erie era have become courts of statutory interpretation. This is nothing new, although it is certainly a phenomenon of this century. Witl the New Deal only fifteen years old, Justice Frankfurter observed that "courts have ceased to be the primary makers of law in the sense in which they 'legislated' the common law."1 Statutes are the federal courts' daily bread. The way in which courts go about reading those statutes in the federal system is therefore of particular importance to our jurisprudence.

* United States Circuit Judge, United States Court of Appeals for the District of Columbia Circuit.

1. Frankfurter, Some Reflections on the Reading of Statutes, 47 CoLUM. L. REv. 527, 527 (1947). 


\section{B. The Courts and the Agencies.}

Even as the federal courts have sought to adapt to the changing nature of their work, the statutes that the courts are charged with interpreting have themselves changed. Courts are less frequently faced with questions concerning familiar statutes such as the Interstate Commerce Act and the Federal Trade Commission Act. Instead, recent enactments such as the Clean Air and Clean Water Acts, the Resource Conservation and Recovery Act, the Natural Gas Policy Act, the Transportation Deregulation Acts, and the Cable Television Act tend to dommate the federal docket.

The substantive complexity of these statutes presents additional problems to the courts. Courts are often ill equipped to master the complexities of these sometimes labyrinthine statutes that govern highly technical matters beyond the expertise of a generalist judiciary. In addition to the complexity of the subject matter, these statutes often regulate technologies not even in existence when the governing statute was enacted. In such cases, the courts are faced with a daunting search reminiscent of Erie: attempting to figure out what a reasonable Congress would decide if the specific issue were put before it.

Against this statutory backdrop are the now ever-present agencies. Since 1887, Congress increasingly has refused to pass a statute and set it out to sea without an escort. Congress thus tends to entrust statutes to administrative agencies. There are other statute readers out there nowcompetitors of the courts. Not so long ago, the federal courts could examine a statute and comfortably render their interpretation, knowing that issues of law, as distinct from issues of fact or mixed issues of law and fact, were questions for the judiciary alone. As opposed to the courts, the Executive was the political branch of policy formulation and implementation, not the branch of quiet, careful reading of statutes and dispassionate, neutral legal analysis. Therefore, one would not expect agencies to decide questions of law authoritatively.

Agencies, nevertheless, enjoy an interpretative role by the very nature of their creation. To take action, they have to construe their statutory charters both in regard to the reach of those charters and with respect to a variety of other day-to-day matters. Thus, agencies do, in fact, decide questions of law. In response, the federal courts have developed a rule of deference-perhaps as a part of democratic theory; perhaps, the cynic might say, just as much out of a sense of fatigue and frustration. 


\section{Deference to Agency Decisions and Chevron.}

The deference principle has seen its fullest explication in Chevron U.S.A. Inc. v. Natural Resources Defense Council, Inc. ${ }^{2}$ and its progeny. The post-Chevron decisions are generally viewed as pro-agency, calling on the courts-in the wake of that broadside in the 1970s, Vermont Yan$k_{e}{ }^{3}$ - to exercise care and respect before rejecting an administrative interpretation of a measure passed by Congress. We are now living not only in the modern administrative state, but also in the post-Vermont Yankee and post-Chevron environment.

Although Chevron calls for the courts to exercise deference to administrative decisions, there is another, often overlooked side to Chevron: its call for a return to traditional principles of statutory interpretation. After Chevron, the courts are not to begin by examining the agency's interpretation; instead, the courts are to look to the statute itself to ascertain what Congress intended. ${ }^{4}$ Since both courts and agencies are bound by the will of the legislature on issues of statutory interpretation, Congress's intent controls, not the agency's. Thus, Chevron has brought back into sharp focus the importance of reading statutes-instead of reading the agencies' reading of statutes.

\section{The Role of Legislative INTENT}

Over the years, the Supreme Court has set forth rules and principles to guide statutory interpretation. The role of the lower federal courts is, of course, to follow those teachings faithfully. The purpose of this discussion, however, is to examine in an extrajudicial setting the wisdom of employing legislative history to divine the intent-the meaning-of the statutes that the article one branch has enacted.

\section{A. Methods of Interpreting Legislative Intent.}

Generally speaking, two competing schools of thought exist with respect to the wisdom and legitimacy of using extrastatutory materials in the interpretation of statutes. The first, with which we are intimately familiar, is the American rule, which smiles upon and ordains the use of legislative historical materials in the interpretative process. The classic statement of the American rule was set forth by Justice Frankfurter in his 1947 Cardozo Lecture: "If the purpose of construction is the ascertainment of meaning, nothing that is logically relevant should be ex-

2. 467 U.S. 837 (1984).

3. Vermont Yankee Nuclear Power Corp. v. Natural Resources Defense Council, Inc. 435 U.S. 519 (1978).

4. See Chevron, 467 U.S. at $842-43$. 
cluded."5 Statutes are, as the Justice put it, "organisms which exist in their environment." 6 The neutral, dispassionate judge will therefore seek to understand the environment whence the statute came.

The second school of thought on the use of legislative history is typified by the English rule, which forswears any use of parliamentary materials in the determination of the statute's meaning. Thus, as Walter Bagehot put it, although the "nation, indeed, generally looks to the discussions in Parliament to enlighten it as to the effect of Bills," the English courts emphatically do not. ${ }^{7}$ The classic statement of this rule was set forth long ago, in 1769:

The sense and meaning of an Act of Parliament must be collected from what it says when passed into a law; and not from the history of changes it underwent in the house where it took its rise. That history is not known to the other house or to the Sovereign. ${ }^{8}$

Early American practice was generally loyal to the English rule. American courts, however, later departed from the English approachthe amusement of foreign courts at this departure culminatimg in the Canadian quip that "in the United States whenever the legislative history is ambiguous it is permissible to refer to the statute." The increasing use of legislative history is most graphically seen in statistical surveys of the opinions of the Supreme Court. In 1938, the Court referred to legislative history nineteen times, but by the 1970 s the Court was making three to four hundred references each term..$^{10}$

Discussions of the use of legislative history generally focus on evaluating the probative value of specific items of history: of committee reports versus congressional debates; of "hot" debates versus canned colloquies, either with or without "bullets"; and of discerning what James Landis almost 60 years ago described as extrinsic aids with real and not illusory significance. ${ }^{11}$ In view of the well-settled nature of the American rule-and indeed its flourishing of late-it might seem iconoclastic to articulate reservations about the use of legislative history in principle. Throwing caution to the winds, it is to these observations that I now turn.

5. Frankfurter, supra note 1 , at 541 .

6. $I d$.

7. W. Bagehot, The English Constitution 10 (2d ed. 1873).

8. Millar v. Taylor, 4 Burr. 2303, 2332, 98 Eng. Rep. 201, 217 (1769) (quoted in Frankfurter, supra note 1, at 541). .

9. R. Dickerson, The Interpretation and Application of Statutes 164 (1975).

10. Carro \& Brann, The U.S. Supreme Court and the Use of Legislative Histories: A Statistical Analysis, 22 JURIMETRICS J. 294, 298 (1982).

11. Landis, A Note on "Statutory Interpretation," 43 HARv. L. Rev. 886, 893 (1930). 


\section{B. The Use of Legislative History.}

The concerns about the use of legislative history fall into two broad categories. The first I would label democratic theory concerns; the second category I would suggest more humbly as practical day-to-day concerns. Taken together, these concerns suggest that the dangers inherent in the use of legislative history generally outweigh the arguable advantages resulting froin its use.

1. Democratic Theory Concerns. Under democratic theory, the statute rather than extrastatutory materials governs the nation. Legislative history, however, has the potential to inute (or indeed override) the voice of the statute itself. In terms of democratic theory, the use of legislative history can distort the proper voice of each branch of our constitutional government. The effect on Congress, the Executive, and the courts will be examined in turn.

The enacted statute definitively represents the avowed "intent" of the Congress as a whole. Legislative materials abound with records of the myriad of congressional "subdivisions"-subcommittees, committees, and ultimately two-house conference committees. These records, however, at best can shed light only on the "intent" of that small portion of Congress in which such records originate; they therefore lack the holistic "intent" found in the statute itself. Thus, although congressional committees are reservoirs of expertise and technical knowledge, by the same token committees inay be narrow and parochial in their outlook, less balanced on the subject in question than the Congress as a whole. Relying on extrastatutory inaterials therefore raises the danger that unrepresentative materials will be accepted as authoritative. ${ }^{12}$

The great flood of legislative history suggests that members of Congress can scarcely be expected to master the secondary inaterials of the bills upon which they vote. Indeed, the members may be divided on whether the history reflects their understanding-a phenoinenon captured in the colloquy between Senators Dole and Armstrong quoted in then Judge Scalia's concurring opinion two years ago in Hirschey $v$. $F E R C .{ }^{13}$ Even in the setting of the congressional committee, in many cases the report adopted will likely not even have been reviewed, much less written or studied, by all members. Given these practical realities, only the record of speeches on the floor of either chamber should be considered even minimally probative of Congress's intent. At least those re-

12. Wald, Some Observations on the Use of Legislative History in the 1981 Supreme Court Term, 68 IOWA L. REV. 195, 202 (1983).

13. 777 F.2d 1, 7 n.1 (D.C. Cir. 1985) (Scalia, J., concurring). 
marks have been heard-however superficially-by members of Congress (albeit a minority in most instances). ${ }^{14}$

Legislative history also minimizes or ignores the role of the Executive. In carrying out his constitutionally ordained functions, the President passes upon legislation, and as a practical matter does so without the benefit of legislative history. In this regard, the President's view of the statute may be different from that of the Congress, and from the subsequent interpretation rendered by the courts. Judicial interpolation of the statute based upon legislative materials thus has the potential to create a statute that the President would not have signed.

The use of legislative history has the further danger of introducing the voice of the federal courts-the nonpolitical branch-into the political process of legislation. In using legislative materials, the courts create winners and losers in the legislative process: elevating the views of some and denigrating or rejecting the views of others. Reflecting this concern, Justice Jackson stated that "political controversies which are quite proper in the enactment of a bill ... should have no place in its interpretation." 15 By using legislative history, the courts may be acting in an area that should be out of bounds to the unelected branch. Therefore, given the effects on Congress, the Executive, and the courts, we would do well to follow Justice Cardozo's admonition: "We take the statute as we find it." 16

2. Practical Concerns. In addition to concerns founded upon democratic theory, a variety of practical reasons counsel restraint in reliance on legislative history. These concerns fall into three groups: the potential for abuse, the cost of usage, and fictitious use.

The most compelling and widely discussed concern about the use of legislative history is its potential for manipulation. It is often said that one generally finds in the legislative history only that for which one is looking. By the same token, an overready reliance on legislative history may become an end in itself, and thus an obstacle to the difficult task of determining the meaning of the statute. Lobbyists maneuver to get their clients' opinions into the mass of legislative materials; judges, in turn, may be tempted to use the convenient tool of legislative history as an

14. Even the debates on the floor nay be less probative today. In the early part of this century, when courts began to rely more frequently on legislative history, the debates on the floor of the Congress could fairly be characterized as an actual sharing and exchange of views between the members. The accuracy of this characterization of current congressional "debate" is questionable.

15. Schwegmann Bros. v. Calvert Distillers Corp., 341 U.S. 384, 396 (1951) (Jackson, J., concurring).

16. Anderson v. Wilson, 289 U.S. 20,27 (1933). 
escape from the hard work of actual judging. Both routes are equally undesirable.

It is well known that technocrats, lobbyists and attorneys have created a virtual cottage industry in fashioning legislative history so that the Congress will appear to embrace their particular view in a given statute. While some aspects of this occupation are legitimate, this history-making can also work an abuse of the legislative process. Perhaps the clearest example is the creation of legislative history after the event of passage, a phenomenon recently noted by the Supreme Court in Clarke v. Securities Industry Association. ${ }^{17}$ In Clarke, the Court discounted the views of a key legislator because his observation had been added ten days after passage of the act. ${ }^{18}$ This is not, to those familiar with the Washington scene, an unfamiliar phenomenon; indeed, the development of iegislative history after the passage of a statute has resulted in well-recognized and much needed reforms such as the so-called "bullet" reform in 1978, which required the clear marking of insertions into the Congressional Record. Nevertheless, the practice of post-enactment creation of "legislative history" still occurs with regnlarity.

Substantial monetary costs are also imposed by the accumulated masses of legislative history produced by the Congress on any given measure. Resort to legislative history forces lawyers not only to study the statute, but also to wade through formidable mounds of materials at federal depositories. Counsel can no longer afford to prepare a case without examining the legislative history, and as the search time grows, the transaction costs increase. Years ago, Justice Jackson expressed a similar concern over the accessibility of pertinent secondary material, when in his Public Utilities Commission concurrence he maintained that prior to the argument, counsel for the California Commission had been unable to secure the background materials. ${ }^{19}$

But the transaction costs do not exist only at the litigation stage. If legislative history "counts" in the adjudicatory setting, then it has to "count" in the nonlitigation counseling setting as well. This point was emphasized by Professor Dickerson, an outspoken critic of resort to legislative history:

It is hard enough to search a long, heterogeneous and often conflicting legislative history as relates to a particular issue in a current controversy. It is vastly harder and impracticable to search all aspects of the legislative history as they relate to the myriad of potentially trouble-

17. 107 S. Ct. 750 (1987).

18. Id. at 761 .

19. United States v. Public Utils. Comm'n, 345 U.S. 295, 319-20 (1953) (Jackson, J., concurring). 
some problems that the lawyer would like to anticipate. ${ }^{20}$

Moreover, the costs extend beyond the bar and its clients: the judiciary must also devote time searching through mountains of material. This task is often fruitless, as reflected by the comments of Justice Jackson: "Legislative history here as usual is more vague than the statute we are called upon to interpret."21 This increases the already well-publicized concerns over an unduly bureaucratized judiciary that leans too heavily upon its staff.

The use of legislative listory may also encourage high fiction in interpreting statutes. A recent example is the Cal Fed case, which concerned pregnancy benefits under Title VII.22 In Cal Fed, a majority of the Supreme Court referred to a House Report, which in turn referred to the lavs of numerous states. The Court concluded that Congress-not the Committee or the chamber that produced the report-must have been aware of the substantive provisions of the various states' laws, since those laws were mentioned in the report. ${ }^{23}$ Reliance on this source, not surprisingly, was called into question by Justice White and his two fellow dissenters. ${ }^{24}$

In addition, the notion of "legislative intent" may in itself be fictitious. The Court now and then reminds us that "legislative imtention, without more, is not legislation." 25 This notion has venerable roots. As Justice Holmes remarked, "We do not inquire what the legislature meant; we ask only what the statute means."26 Justice Jackson echoed this theme in his famous concurrences in Schwegmann Brothers ${ }^{27}$ and Public Utilities Commission, ${ }^{28}$ where he bemoaned the Court's decision to forswear "analysis of the statute" and embrace instead "psychoanalysis of Congress."29 Chief Judge Wald, in her study of Supreme Court opinions during the 1981 term, concluded that in the majority of those cases the opinion writers disagreed as to either the substance or the thrust of the legislative history. ${ }^{30}$ Thus, in the majority of those opin-

20. R. DICKERSON, supra note 9, at $150-51$.

21. Public Utils. Comm'n, 345 U.S. at 320 (Jackson, J., concurring).

22. California Fed. Sav. \& Loan Ass'n v. Guerra, 107 S. Ct. 683 (1987).

23. Id. at $692-93 \& \mathrm{nn} .23-25$.

24. Id. at 700-01 (White, J., dissenting, joined by Rehnquist, C.J., and Powell, J.).

25. Train v. City of New York, 420 U.S. 35, 45 (1975).

26. O.W. Holmes, The Theory of Legal Interpretation, in Collected Legal Papers 207 (1920).

27. Schwegmann Bros. v. Calvert Distillers Corp., 341 U.S. 384, 395-97 (1951) (Jackson, J., concurring).

28. United States v. Public Utils. Comm'n, 345 U.S. 295, 319-21 (1953) (Jackson, J., concurring).

29. Id. at 319.

30. Wald, supra note 12, at 207. 
ions-both concurrences and dissents-the legislative history was viewed as inconclusive. Even if the legislative history does appear to support one position or another, the Court often finds that the "apparent" meaning of the statutory text itself is more persuasive than the legislative history. As Justice Frankfurter commented in his Cardozo Lecture forty years ago, "no one will gainsay that the function in construing a statute is to ascertain the meaning of words used by the legislature. To go beyond it is to usurp a power which our democracy has lodged in its elected legislature." 31

\section{CONCLUSION}

Interpreting congressional intent has become increasingly important since Chevron declared that agency decisions must be evaluated in light of that intent. However, the benefits accruing from the use of legislative history are marginal when weighed against the potential for abuse and the enormous effort involved. In hight of the democratic theory and practical considerations counseling against undue reliance on legislative history, one might wonder whether the effort of poring over mountains of legislative materials is worth the candle. If not, the law might be better served by a movement toward the English rule that prevailed in early American practice, at least to the extent that legislative history is employed only when every other avenue of determining the meaning of Congress has failed.

31. Frankfurter, supra note 1 , at 533 . 